\title{
Production of lignocellulolytic enzymes from floriculture residues using Pleurotus ostreatus
}

\author{
Balkys Quevedo-Hidalgo ${ }^{1 \bowtie}$,Paulo Cesar Narváez-Rincón ${ }^{3}$, \\ Aura Marina Pedroza-Rodríguez ${ }^{2}$, Mario Enrique Velásquez-Lozano ${ }^{4}$
}

\begin{abstract}
Floriculture is a vital agro-industrial sector in the Colombian economy; the export of flowers positively impacts employment and the balance of trade. However, this industry could negatively impact the environment if its waste products are not handled properly. These flower residues, rich in lignin, hemicellulose and cellulose, could be a cost-effective raw material to produce enzymes. Here, we evaluate the production of lignocellulolytic enzymes by degradation of Chrysanthemum and Rosa residues using Pleurotus ostreatus, and manganese sulfate and copper sulfate as inductors. From the two residues, we obtained laccase, manganese peroxidase, endoglucanase, exoglucanase, and $\beta$-glucosidase. The use of inductors, favored all enzyme activities except for $\beta$-glucosidase. The enzymes that displayed the highest activity were laccase $(4,693.4 \mathrm{U} / \mathrm{L}$ and 2,640 U/L from the residues of Chrysanthemum and Rosa, respectively) and $\beta$-glucosidase (9,513 U/L and 6,811.9 U/L). The enzyme that showed the lowest activity was endoglucanase (11.5 U/L and 15.4 U/L). Under the conditions evaluated, the best substrate for enzyme production is Chrysanthemum wastes; the extracts obtained had higher enzymatic activity than the extracts from Rosa residues.
\end{abstract}

Keywords: floriculture residues; Chrysanthemum; Rosa; lignocellulolytic enzymes; Pleurotus ostreatus

Edited by Alberto Acosta $\bowtie$

1. Grupo de Biotecnología Ambiental e Industrial (GBAI),

Laboratorio de Biotecnología Aplicada, Departamento de

Microbiología, Pontificia Universidad Javeriana. Bogotá, Colombia.

2. Grupo de Biotecnología Ambiental e Industrial (GBAI), Laboratorio de Microbiología ambiental, Departamento de Microbiología, Pontificia Universidad Javeriana.

3. Grupo de Procesos Químicos y Bioquímicos, Laboratorio de Ingeniería Química, Departamento de Ingeniería Química y Ambiental, Universidad Nacional de Colombia. Bogotá, Colombia.

4 Grupo de Procesos Químicos y Bioquímicos, Laboratorio de Ingeniería Química, Departamento de Ingeniería Química y Ambiental, Universidad Nacional de Colombia. Bogotá, Colombia.

Received: 01-06-2014 Accepted: 01-08-2014

Published on line: 08-09-2014

Citation: Quevedo-Hidalgo B, Narváez-Rincón PC, Pedroza-Rodríguez AM, Velásquez-Lozano ME (2015) Production of lignocellulolytic enzymes from floriculture residues using Pleurotus ostreatus. Universitas Scientiarum 20(1): 117-127 doi: 10.11144/Javeriana.SC20-1.eple

Funding: Pontificia Universidad Javeriana; Universidad Nacional de Colombia.

Electronic supplementary material: N/A

\section{Introduction}

Forestry and agricultural activities such as the production of paper, lumber and many other agro industries generate large amounts of waste. These residues are considered an environmental contamination issue. A high percentage of these residues are indiscriminately burned, generating greenhouse gases, and their outdoor decomposition generates leaching into water bodies and promotes the proliferation of pests (Asocolflores 2002).

Lignocellulose is the major structural component of woody and non-woody plants and represents an important source of renewable organic matter. Lignocellulose contains lignin, hemicellulose and cellulose, compounds with chemical properties 
that increase the biotechnological potential of the lignocellulosic substrate (Malherbe \& Cloete 2002). To exploit the potential of lignocellulose as feedstock to produce high added-value products, a physical, chemical or biological pretreatment process is always necessary to modify its three-dimensional structure. Some biological pretreatments have been studied, among these; degradation using enzymes produced by fungi (Stajić et al. 2006, Membrillo et al. 2008, Bettin et al. 2011, Větrovský et al. 2013), including the lignocellulosic degradation using $P$. ostreatus (Isikhuemhen \& Mikiashvilli 2009, Quevedo-Hidalgo 2012, Thakur et al. 2013).

P. ostreatus is a white rot basidiomycete that grows on a variety of agricultural lignocellulosic residues and produces a great number of extracellular enzymes. For example, Baldrian et al. (2005) reported the production of cellulolytic and hemicellulolytic enzymes endo-1,4- $\beta$-glucanase, exo-1,4- $\beta$-glucanase, $1,4-\beta$-glucosidase, endo- $1,4-\beta$ xylanase, $1,4-\beta$-xylosidase, endo-1,4- $\beta$-mannanase and 1,4- $\beta$-mannosidase, and ligninolytic enzymes such as Mn-peroxidase and laccase, by growing $P$. ostreatus on wheat straw in the presence and absence of $\mathrm{Cu}, \mathrm{Mn}, \mathrm{Pb}$, and Zn. Elisashvili et al. (2006) studied the production of cellulase, xylanase, laccase and manganese peroxidase in submerged fermentation of mandarin peels and tree leaves. Thakur et al. (2013) reported the production of ligninolytic enzymes using $P$. ostreatus from biologically and chemically pretreated wheat straw and banana stem substrates.

A typical fungal cellulolytic system comprises multiple enzymes. Cellulases are usually mixtures of several enzymes, mainly endoglucanase, exoglucanase and $\beta$-glucosidase (Sun \& Cheng 2002). Endoglucanases internally hydrolyze cellulose chains, exoglucanases externally hydrolyze cellobiose units from the non-reducing or reducing ends of cellulose microfibers and 1,4- $\beta$-glucosidase hydrolyzes the bonds linking glucose molecules (Baldrian \& Valášková 2008). By catalyzing the hydrolysis of alkyl- and aryl- $\beta$-glucosides, diglucosides, and oligosaccharides, 1,4- $\beta$-glucosidase plays a considerable role on the decomposition of lignocellulosic substrates; it hydrolyzes cellobiose into glucose, thereby preventing end-product inhibition of exoglucanases (Huang, 2011).
Cellulases and other enzymes with similar or complementary enzymatic pathways are used in the food, beer, wine, animal feed, textile, laundry and paper industries, as well as in agriculture research (Bhat 2000). Laccase and manganese peroxidase are enzymes that have potential industrial applications because these enzymes remove oxidized phenolic compounds and a variety of aromatic compounds. The conversion of toxic compounds and textile dyes present in wastewater and the bleaching and removal of lignin from wood fibers and non-wood are two examples of industrial applications of these enzymes (Lundell et al. 2010).

Floriculture is one of the main activities of the agricultural sector in Colombia, with a $13 \%$ share of the world trade of flowers, ranking second after the Netherlands, which has a $42 \%$ market share. According to Asocolflores (2010), more than 50 types of flowers are produced over an area of 7,266 hectares in Colombia. The main types of flowers are Rosa (33\%), carnations (12.7\%), mini carnations (6.7\%), Chrysanthemum and pompons (8 \%) (Asocolflores 2010). The floriculture sector generates approximately $1.5 \mathrm{~m}^{3} / \mathrm{ha} /$ day or between 0.8 and $1 \mathrm{t} / \mathrm{ha} /$ week of vegetable residues, depending on the type of flower and the production cycle. Approximately 9,591 t/month of residues are generated by Rosa production while 2,325 t/month are generated by Chrysanthemum cultures. Residues result from the cutting, postharvesting and planting startup steps.

Considering the volume of floriculture residues generated in Colombia and the fact that enzyme production from floriculture wastes has not been reported previously, in this article, we evaluate enzyme production from the degradation of lignocellulose residues of Rosa and Chrysanthemum using P. ostreatus. The production of laccase, manganese peroxidase, endoglucanase, exoglucanase and $\beta$-glucosidase was evaluated after a submerged fermentation process using flower residues and P. ostreatus. Enzyme extracts containing all the enzymes mentioned previously were obtained from the two assessed residues. The process using the Chrysanthemum residues produced the extracts with the highest enzymatic activities. 


\section{Materials and methods}

Cultivos del Norte (Tocancipá, Colombia) supplied the Chrysanthemum and Rosa residues (stems and leaves). The residues were analyzed for lignin, cellulose and hemicellulose contents using the neutral detergent fiber method (NDF) (Van Soest et al. 1991). Phosphorus, calcium, potassium, zinc, magnesium, copper and manganese content was assessed using flame atomic absorption spectrophotometry (Thermo Scientific ICE3000) following the procedure described in ASTM D1971-11 Practice B for digestion and ASTM D469111 for measuring the elements. Nitrogen content was determined by the procedure described in ASTM D5373-08 (Table 1). Before degradation, the residues were dried at $104^{\circ} \mathrm{C}$ for $24 \mathrm{~h}$ and milled to a particle size smaller than $1 \mathrm{~mm}$. All reagents used in this study were of analytical grade. P. ostreatus (HPB/P3) were obtained from the Biotechnology Laboratory of the Pontificia Universidad Javeriana (Bogotá, Colombia). Stock cultures of this fungus were maintained on wheat bran agar at $4{ }^{\circ} \mathrm{C}$.

\section{Enzyme production from Chrysanthemum and Rosa}

Two assays were performed for each residue, one with and one without inductors addition (in total four cultures, each one run by triplicate) to evaluate enzyme production from Chrysanthemum and Rosa.

Fungal inoculum were grown on a static culture at $30 \pm 2{ }^{\circ} \mathrm{C}$ in $250 \mathrm{~mL}$ Erlenmeyer flasks containing 50 $\mathrm{mL}$ of the following (per liter): $50 \mathrm{~g}$ of floriculture wastes, $2 \mathrm{~g}$ of yeast extract, $5 \mathrm{~g}$ of peptone, $0.075 \mathrm{~g}$ of $\mathrm{MnSO}_{4} \cdot \mathrm{H}_{2} \mathrm{O}, 1 \mathrm{~g}$ of $\mathrm{KH}_{2} \mathrm{PO}_{4}, 0.5 \mathrm{~g}$ of $\mathrm{MgSO}_{4} .7 \mathrm{H}_{2} \mathrm{O}$, and $175 \mathrm{~g}$ of wheat bran. This medium was inoculated with ten fungal disks ( $5 \mathrm{~mm}$ diameter) taken from the edge of the mycelium grown on bran extract agar in petri dishes (7-day old). After seven days, mycelial biomass was obtained and was inoculated (5\% of dry mycelium based on substrate volume) to the degradation stage.

The degradation of Chrysanthemum and Rosa residues was performed in a $1.5 \mathrm{~L}$ bioreactor (TECFERM, Procesos Biotecnológicos y Medioambientales, Bogotá, Colombia) with an agitation speed of $240 \pm 5 \mathrm{rpm}$ and aeration rate of $2 \mathrm{vvm}$ for $24 \mathrm{~h}$, with $P$. ostreatus in submerged fermentation under the optimum conditions as determined by QuevedoHidalgo et al. (2012) for reducing sugars. The optimum conditions for Chrysanthemum and Rosa residues were $6.3 \%(\mathrm{w} / \mathrm{v})$ concentration and $\mathrm{pH}$ 5.6, and $11.8 \%(\mathrm{w} / \mathrm{v})$ concentration and $\mathrm{pH} 5.6$, respectively (Quevedo-Hidalgo et al. 2012). For the assays without inductors, $\mathrm{Cu}^{+2}$ and $\mathrm{Mn}^{+2}$ concentrations were the same as those originally present in each residue. For the assays with inductors, copper sulfate and manganese sulfate were added simultaneously; each concentration was $7.5 \mathrm{mM}$.

The culture was separated from the fungal biomass and insoluble components of the culture medium by centrifugation (at 22,000 $\mathrm{g}$ for $15 \mathrm{~min}$ ) at $4{ }^{\circ} \mathrm{C}$, followed by filtration using a Millipore membrane $(0.45 \mu \mathrm{m})$. The extract was stored at $-20{ }^{\circ} \mathrm{C}$ and it was used to determine the presence of the following enzymes: laccase, manganese peroxidase $(\mathrm{MnP})$, endoglucanase, exoglucanase, and $\beta$-glucosidase.

Finally, because Chrysanthemum and Rosa residues contain $\mathrm{Zn}^{+2}$ and $\mathrm{Cu}^{+2}$, we added $\mathrm{Zn}^{+2}$ or $\mathrm{Cu}^{+2}$ to final concentrations of 20,40 and $80 \mathrm{ppm}$ to assess laccase

Table 1. Characterization of the Chrysanthemum and Rosa residues.

\begin{tabular}{|c|c|c|c|c|c|c|c|c|c|c|c|}
\hline & Cellulose & Hemicellulose & Lignin & $\mathbf{N}$ & $\mathrm{Ca}$ & $\mathbf{K}$ & $\mathrm{Mg}$ & $\mathrm{Cu}$ & $\mathrm{Fe}$ & Mn & $\mathrm{Zn}$ \\
\hline Residue & \multicolumn{7}{|c|}{ Content (weight \%) } & \multicolumn{4}{|c|}{ Content (mg/kg) } \\
\hline Chrysanthemum & 49.6 & 7.5 & 17.5 & 2 & 0.63 & 1.78 & 0.26 & 24.6 & 258 & 70.7 & 58.8 \\
\hline Rosa & 38.4 & 8.8 & 9.5 & 1.94 & 0.78 & 0.88 & 0.19 & 8.99 & 256 & 86.3 & 82.3 \\
\hline
\end{tabular}


activity in the extracts. Each assay was performed by triplicate. Laccase activities with added $\mathrm{Zn}^{+2}$ or $\mathrm{Cu}^{+2}$ were compared to the activities obtained without the addition of these metals.

\section{Evaluation of the solid fraction obtained from the degradation process of Chrysanthemum and $R$ os $a$ residues}

Because the solid fraction of the residues can contain adsorbed enzymes, they were washed 5 times by centrifugation with distilled water (at $1,500 \mathrm{~g}$ for $10 \mathrm{~min}$ at $4{ }^{\circ} \mathrm{C}$ ). The remaining solids were re-suspended with $50 \mathrm{mM}$ sodium citrate buffer $\mathrm{pH} 5.0$ and stirred at $150 \mathrm{rpm}$ for two hours at $4{ }^{\circ} \mathrm{C}$. The supernatant was separated by centrifugation at $10,800 \mathrm{~g}$ for $10 \mathrm{~min}$ at $4{ }^{\circ} \mathrm{C}$, then filtered through a $0.45 \mu \mathrm{m}$ Millipore membrane and used to measure the enzymatic activities. The enzymatic activity of the solid fraction was related with the extract to determine the percentage of adsorption. The process was evaluated with and without the addition of these inductors to establish the effects of manganese and copper sulfate on the enzymatic activity.

\section{Enzymatic assays}

All assays were performed in triplicate using an Evolution $60 \mathrm{UV} /$ Visible Thermo spectrophotometer. Laccase activity (EC 1.10.3.2) was determined with the substrate ABTS (2.2'-azinobis (3-ethylbenzthiazoline-6-sulphonic acid) (Sigma, St. Louis, MO, USA). The assay mixture contained $100 \mu \mathrm{L}$ of $0.5 \mathrm{mM}$ ABTS, $100 \mu \mathrm{L}$ of $60 \mathrm{mM}$ sodium acetate buffer ( $\mathrm{pH} 4.5$ ), and $800 \mu \mathrm{L}$ of the culture filtrate; the reaction was carried out during 3 min. Oxidation of ABTS was monitored by measuring the absorbance increase at $436 \mathrm{~nm}\left(\xi_{436}=29,300\right.$ $\left.\mathrm{M}^{-1} \mathrm{~cm}^{-1}\right)$. One unit of laccase activity was defined as $1 \mu \mathrm{mol} \mathrm{ABTS}{ }^{+}$formed per minute (Bourbonnais et al. 1997, Tinoco et al. 2001).

The manganese peroxidase (MnP, E.C. 1.11.1.13) activity was determined by the oxidation of 2.6-dimethoxyphenol (2.6-DMP) (Sigma, St. Louis, MO, USA) at $468 \mathrm{~nm}\left(\xi_{468}=49,600 \mathrm{M}^{-1} \mathrm{~cm}^{-1}\right)$, and the reaction mixture contained $450 \mu \mathrm{L}$ of culture supernatant, $500 \mu \mathrm{L}$ of $10 \mathrm{mM}$ 2.6-DMP in $100 \mathrm{mM}$ sodium acetate buffer ( $\mathrm{pH} 5.0$ ), $50 \mu \mathrm{L}$ of $0.4 \mathrm{mM}$
$\mathrm{MnSO}_{4}$, and $30 \mu \mathrm{L}$ of $22 \mathrm{mM} \mathrm{H}_{2} \mathrm{O}_{2}$; this reaction was carried out during 3 min (Santoyo et al. 2008). Given that both $\mathrm{MnP}$ and laccase can oxidize 2.6-DMP, the laccase activity was subtracted using data from control experiments performed in the absence of $\mathrm{H}_{2} \mathrm{O}_{2}$ and manganese. One unit of $\mathrm{MnP}$ activity was defined as $1 \mu \mathrm{mol}$ of 2.6-DMP oxidized per minute.

The activity of endoglucanase (EC 3.2.1.4) was measured with carboxymethylcellulose (CMC) (low viscosity, Sigma, St. Louis, MO, USA). The reaction mixture contained $1 \mathrm{~mL}$ of $2 \%(\mathrm{w} / \mathrm{v})$ substrate in 50 $\mathrm{mM}$ sodium citrate buffer ( $\mathrm{pH} 5.0)$, and $1 \mathrm{~mL}$ sample (Ghose 1987). The reaction mixture was incubated at $40{ }^{\circ} \mathrm{C}$ for $60 \mathrm{~min}$; the reaction was stopped by boiling the sample for 5 minutes. The sample was then cooled for 5 minutes and centrifuged at 2,500 $\mathrm{g}$ for $15 \mathrm{~min}$. The amount of reducing sugars released was determined using the Somogy-Nelson method (Somogy 1952). A standard curve was obtained by using glucose. One unit of enzyme activity was defined as the amount of enzyme releasing $1 \mu \mathrm{mol}$ of reducing sugars as glucose per min.

The activity of exoglucanase (EC 3.2.1.91) was determined using $p$-nitrophenyl- $\beta$-D-cellobioside (PNPC, Sigma, St. Louis, MO, USA). The reaction mixture contained $160 \mu \mathrm{L}$ of $5 \mathrm{mM}$ PNPC in a 50 $\mathrm{mM}$ sodium acetate buffer $(\mathrm{pH} 5.0)$ and a $40 \mu \mathrm{L}$ sample. Reaction mixtures were incubated at $40{ }^{\circ} \mathrm{C}$ for $60 \mathrm{~min}$. The reaction was stopped by adding $100 \mu \mathrm{L}$ of $0.5 \mathrm{M}$ sodium carbonate, and the absorbance was read at $400 \mathrm{~nm}$. Enzyme activity was calculated by using a standard curve of $p$-nitrophenol. One unit of enzyme activity was defined as the amount of enzyme that released $1 \mu \mathrm{mol}$ of $p$-nitrophenol per min (Valášková \& Baldrian 2006).

The activity of $\beta$-glucosidase (EC 3.2.1.21) was determined using $p$-nitrophenyl- $\beta$-D-glucoside as the substrate (PNPG, Sigma, St. Louis, MO, USA) with the same method described for exoglucanase (Valášková \& Baldrian 2006).

\section{Statistical analysis}

To establish significant differences between Chrysanthemum and Rosa residues as substrates and with and without inductors, we performed an ANOVA with Tukey test using a confidence interval 
of $95 \%(\alpha=0.05)$. Data were tested for normality (Shapiro-Wilk) and subjected to the Levene test for homogeneity in the group variances. In all the cases, differences of $\mathrm{p}<0.05$ were regarded as statistically significant. SAS 9.0 for Windows was used.

\section{Results}

\section{Enzyme production from Chrysanthemum and Rosa}

According to the ANOVA, statistically significant differences were observed for the enzymatic activity of laccase, exoglucanase and $\beta$-glucosidase $(p<0.0001)$, and for endoglucanase $(p=0.0007)$, between the different cultures completed.

The enzymatic activities of Chrysanthemum residues were higher than those of Rosa residues, except for endoglucanase (Figure 1). Regarding the enzymes involved in the degradation of lignin, laccase and $\mathrm{MnP}$, the maximum enzyme activity for both residues was obtained by adding inductors. The behavior of endoglucanase and $\beta$-glucosidase was different and the maximum enzyme activity for both residues was obtained without inductors (Figure 1). The addition of inductors did not increase exoglucananse enzymatic activity.

Enzyme activities for the degradation of Chrysanthemum residues were 4,693.4 U/L and 673.8 U/L for laccase and for $\mathrm{MnP}$, respectively (Table 2). Laccase activity was 4.8 times higher when the inductors $\mathrm{Cu}^{+2}$ and $\mathrm{Mn}^{+2}$ were added, while the $\mathrm{MnP}$ activity was $62 \%$ higher. On the other hand, the behavior for endoglucanase and $\beta$-glucosidase was different, and the presence of inductors decreased their activity. The addition of inductors reduced the

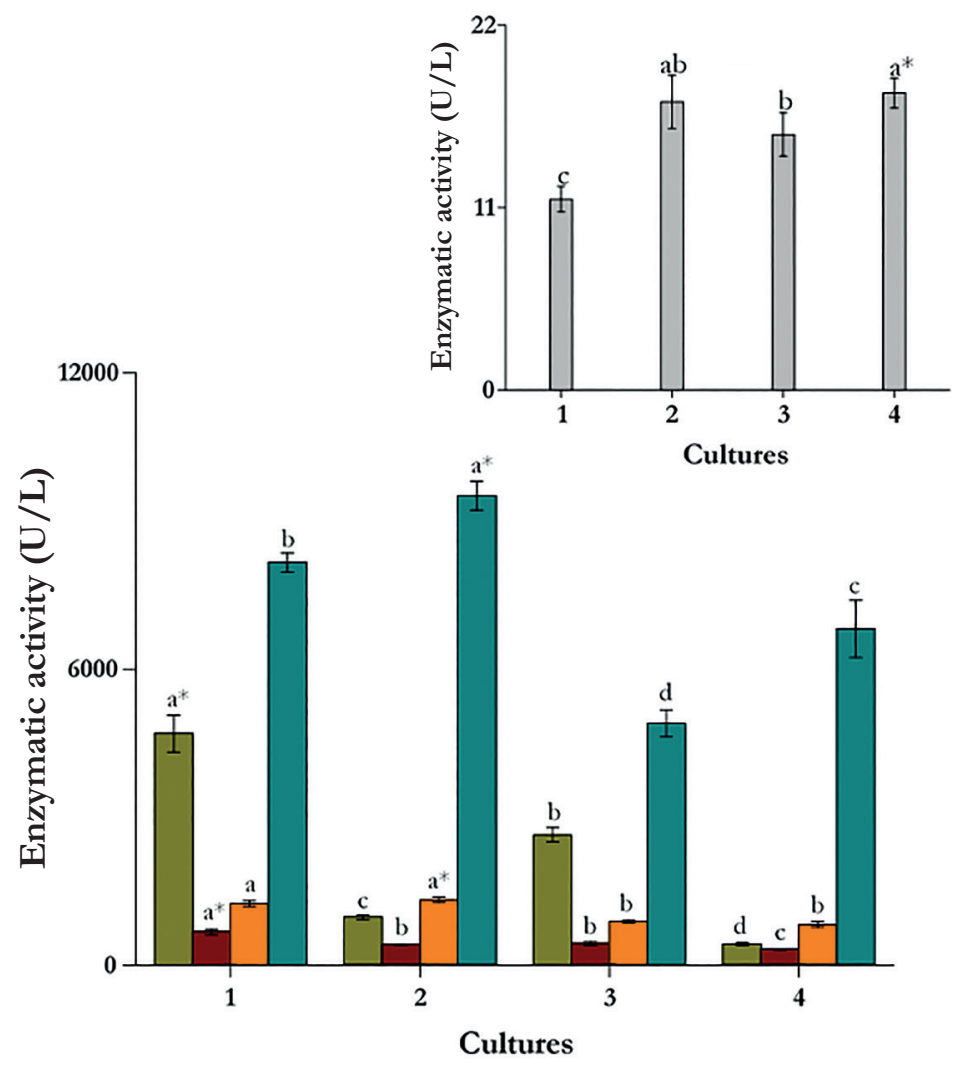

Fig. 1. Enzymatic activity as a function of the residue used as substrate and the presence of inductors. Culture 1: Chrysanthemum residues with inductors. Culture 2: Chrysanthemum residues without inductors. Culture 3: Rosa residues with inductors. Culture 4: Rosa residues without inductors. Laccase MnP Endoglucanase $\beta$-glucosidase Exoglucanase $\square$. Letters represent Tukey homogeneous subsets. a* corresponds to the culture with the best activity for each enzyme, followed in order by a, b, c and d.

Table 2. Enzyme activity in the liquid extract after the degradation of the Chrysanthemum residue using P. ostreatus.

\begin{tabular}{lll}
\hline Enzyme & With inductors & Without inductors \\
\hline Laccase (U/L) & $4,693.4 \pm 374.9$ & $974.1 \pm 40.3$ \\
$\mathrm{MnP}(\mathrm{U} / \mathrm{L})$ & $673.8 \pm 58.4$ & $415.7 \pm 9.9$ \\
Endo-1,4- $\beta$-glucanase (U/L) & $11.5 \pm 0.8$ & $17.4 \pm 1.6$ \\
Exoglucanase (U/L) & $1,248.7 \pm 57.5$ & $1,325 \pm 55.6$ \\
$1,4-\beta$-glucosidase (U/L) & $8,158.3 \pm 189.7$ & $9,513 \pm 291.7$ \\
\hline
\end{tabular}


Table 3. Enzyme activities in the liquid extract after the degradation of the Rosa residue using P. ostreatus.

\begin{tabular}{lcc}
\hline Enzyme & With inductors & Without inductors \\
\hline Laccase (U/L) & $2,640 \pm 142.3$ & $429 \pm 29$ \\
$\mathrm{MnP}(\mathrm{U} / \mathrm{L})$ & $439.2 \pm 35$ & $322 \pm 12$ \\
Endo-1,4- $\beta$-glucanase (U/L) & $15.4 \pm 1.3$ & $17.9 \pm 0.9$ \\
Exoglucanase (U/L) & $884.3 \pm 28$ & $825.6 \pm 56$ \\
$1,4-\beta$-glucosidase (U/L) & $4,900.3 \pm 275.5$ & $6,811.9 \pm 577.2$ \\
\hline
\end{tabular}

enzymatic activity about $34 \%$ and $14 \%$, respectively. When inductors were added, exoglucanase activity decreased to less than $6 \%$.

Regarding the enzymes involved in the degradation of lignin from Rosa residues, the maximum enzyme activity was 2,640 U/L for laccase and 439.2 U/L for $\mathrm{MnP}$ when inductors were used (Table 3). When $\mathrm{Cu}^{+2}$ and $\mathrm{Mn}^{+2}$ were added, the activities of these enzymes increased six times and $36 \%$, respectively. As described for Chrysanthemum residues, the addition of inductors reduced the enzymatic activity of endoglucanase and $\beta$-glucosidase. Their activities were reduced about $14 \%$ and $28 \%$, respectively. Unlike the behavior observed with Chrysanthemum residues, exoglucanase activity augmented $7 \%$ when inductors were added.

$\mathrm{Cu}^{+2}$ addition increased laccase activity in all cases (Table 4), whereas the addition of $\mathrm{Zn}^{+2}$ decreased it in both Chrysanthemum and Rosa extracts (Table 4). The maximum reduction in activity was found in Rosa extract.

Evaluation of the solid fraction obtained from the degradation process of Chrysanthemum and Rosa residues

The presence of enzymes in the solid fraction was assessed to check whether they were adsorbed in the

Table 4. Enzyme activities in the liquid extract after the degradation of the Rosa residue using P. ostreatus.

Increase in laccase activity $(\%)$

Final $\mathrm{Cu}^{+2}$

concentration in the

enzymatic reaction

Chrysanthemum Rosa

Reduction in laccase activity (\%)

Final $\mathrm{Zn}^{+2}$

concentration in the enzymatic reaction

20 ppm

10

13

19
20 ppm

0.2

12

Chrysanthemum

40 ppm

8

21

30 
Table 5. Enzyme activities in the solid fraction after the degradation of the Chrysanthemum and Rosa residues using P. ostreatus. Data are the average of three measurements \pm SD.

\begin{tabular}{|c|c|c|c|c|}
\hline \multirow{3}{*}{ Enzyme } & \multicolumn{2}{|c|}{ Chrysanthemum } & \multicolumn{2}{|c|}{ Rosa } \\
\hline & & & & \\
\hline & Activity (U/L) & Adsorption (\%) & Activity (U/L) & Adsorption (\%) \\
\hline Laccase & $203.2 \pm 6.6$ & 4 & $281.2 \pm 9.6$ & 9.6 \\
\hline $\mathrm{MnP}$ & $28.8 \pm 2.5$ & 4 & $118.1 \pm 6.2$ & 21.2 \\
\hline Endo-1,4- $\beta$-glucanase & $5.5 \pm 0.5$ & 32.4 & $6.5 \pm 0.5$ & 29.6 \\
\hline Exoglucanase & $20.80 \pm 2.1$ & 1.6 & $814.4 \pm 14.1$ & 48 \\
\hline 1,4- $\beta$-glucosidase & $438.13 \pm 18.8$ & 5 & $210 \pm 15$ & 4.1 \\
\hline
\end{tabular}

residue. For both residues, in all cases, the enzyme activity was higher in the liquid fraction than in the solid (Table 5). The percentage of adsorbed laccase enzymes was low for both residues. Approximately $30 \%$ of the endoglucanase was adsorbed for both residues.

\section{Discussion}

\section{Enzyme production from Chrysanthemum and Rosa}

The laccase activity obtained in this study was higher than the activity reported by other researchers using $P$. ostreatus and measuring the enzymatic activity with ABTS. For example Isikhuemhen \& Mikiashvilli (2009) obtained 164.6 U/L for laccase from wheat straw mixed with solid waste obtained from the anaerobic digestion of litter from the commercial production of broiler chickens. Another example is the study developed by Větrovský et al. (2013); these authors reported $16.7 \mathrm{mU} / \mathrm{ml}$ when laccase was produced from a synthetic CLN medium with cellulose as the source of carbon and high $\mathrm{C} / \mathrm{N}$ ratio typical of wood. The highest laccase activity obtained by these authors was $206.8 \mathrm{mU} / \mathrm{ml}$ using Fomes fomentarius.
As previously mentioned, the addition of inductors increased the laccase activity 4.8 times with Chrysanthemum and 6 times with Rosa. Other authors have reported the effect of the inductors, copper and manganese, in improving laccase activity depending on the substrate, organism, crop, and the concentrations of these metals (Giardina et al. 2000, Baldrian et al. 2005, Stajić et al. 2006, Lu \& Ding 2010). For example, Baldrian et al. (2005) reported that average laccase activity increases $79 \%$ with $\mathrm{Cu}$ addition in cultures of P. ostreatus on wheat straw. Stajić et al. (2006) reported peaks of laccase activity, grown on dry mandarin peels, which depended on the concentration of $\mathrm{Cu}^{+2}$, the time of cultivation and the P. ostreatus strain.

According to the characterization of the waste (Table 1), the copper contents in the residues of Rosa and Chrysanthemum were $8.99 \mathrm{ppm}$ and $24.6 \mathrm{ppm}$, respectively. This difference explains why laccase activity was higher when Chrysanthemum residues were used as a substrate. Copper induces laccase activity, as reported in cultures of Trametes versicolor (Collins 1996), P. ostreatus (Palmieri 2000), Trametes pubescens (Galhaup \& Haltrich 2001), and Botryosphaeria sp. (Dekker \& Barbosa 2001), and P. ostreatus (Tinoco et al. 2011). However, some studies have showed that high copper concentrations can be inhibitory (Murugesan et al. 2009). 
The lignin content is another factor that may influence the difference found in the laccase activity of these residues. The lignin content was $17.5 \%$ for Chrysanthemum residues and $14.8 \%$ for Rosa residues (Table 1). Tinoco et al. (2011) observed that the addition of lignin to the culture medium had a strong positive influence on the production of laccase by $P$. ostreatus. When copper was added simultaneously, the activity of that enzyme was higher than the sum of the values determined using each inductor separately; this shows a synergistic effect on the production of the enzyme (Tinoco et al. 2011). The lignin and copper contents in Chrysanthemum residues are higher than those in Rosa residues (Table 1), explaining why laccase activities were higher in the former residue.

The $\mathrm{MnP}$ activity increased $62 \%$ and $36 \%$ with the addition of inductors for Chrysanthemum and Rosa residues, respectively. The addition of $\mathrm{Mn}^{+2}$ can have positive or negative effects on the $\mathrm{MnP}$ activity; as a result, this metal must be evaluated for each process. For example, Giardina et al. (2000) produced MnP using P. ostreatus in a solid culture of poplar sawdust; they reported an increase in the $\mathrm{MnP}$ activity as a consequence of the addition of $\mathrm{Mn}^{+2}$ to the culture. On the other hand, Baldrian et al. (2005), reported that the $\mathrm{MnP}$ activity was negatively affected by the presence of $\mathrm{Mn}^{+2}, \mathrm{Cu}^{+2}$ and $\mathrm{Pb}^{+2}$ and that the $\mathrm{MnP}$ activity was lower in the presence of $\mathrm{Mn}^{+2}$ than in the absence of this metal when P. ostreatus was cultured on lignocellulose.

Concerning the evaluation of the enzymes involved in the degradation of cellulose, the results show that the enzyme complex necessary to hydrolyze cellulose was present in the obtained extract. According to the results of this work, the activity of $\beta$-glucosidase stresses the production from Chrysanthemum and Rosa residues, with or without inductors, because the activities are higher than the values reported by other studies. For instance, Větrovský et al. (2013) obtained an activity of $3.88 \mathrm{U} / \mathrm{ml}$ using a synthetic medium while the value obtained in our work was 9,513 U/L using Chrysanthemum residue without inductors. The activities of endo- and exo-glucanases were different with and without inductors, so we can affirm that copper and manganese have effect on the activity of these enzymes, although this is less important than the effect of these inductors on laccase and MnP.
The activity of $\beta$-glucosidase was $14 \%$ lower when the process was performed with the addition of copper and manganese. That reduction can be explained because copper is an inhibitor as reported by Lin et al. (2010). These authors found that the presence of $\mathrm{Cu}^{+2}(0.1 \mathrm{mM})$ inhibited the activity of $\beta$-glucosidase, and this activity was not increased by the addition of $\mathrm{Mn}^{+2}(0.1 \mathrm{mM})$.

Enzymes that exhibited activity after the degradation of the Chrysanthemum and Rosa residues have several industrial uses. For example, laccase is used in industrial processes such as bleaching of stains and the degradation of polycyclic aromatic hydrocarbons; $\beta$-glucosidase also plays an important role in the degradation of lignocellulosic substrates. The addition of $\beta$-glucosidase speeds up sugar production, which is the end product of the degradation of lignocellulosic substrates. This enzyme catalyzes cellobiose hydrolysis, avoiding inhibition of endoglucanase and exoglucanase synthesis (Kumar et al. 2008). Therefore, establishing the production conditions to obtain $\beta$-glucosidase with high activity $(9,513 \mathrm{U} / \mathrm{L})$ and productivity $(396.4 \mathrm{U} / \mathrm{L} / \mathrm{h})$ is an essential contribution to the study of the hydrolysis of cellulose.

Because the effects of copper and zinc on laccase activity can be either positive or negative, we conducted experiments adding these metals to laccasecatalyzed reactions. Results showed that laccase activity increased with the addition of $\mathrm{Cu}^{+2}$ and diminished with the addition of $\mathrm{Zn}^{+2}$. The effect of zinc can be explained by the results of Murugesan et al. (2009). Their results indicated that laccase activity increased when $\mathrm{Ca}^{+2}, \mathrm{Cu}^{+2}, \mathrm{Co}^{+2}$ and $\mathrm{Zn}^{+2}$ ions were added to the culture medium at low concentrations (up to $1 \mathrm{mM}$ ), and decreased if the concentrations of $\mathrm{Cu}^{+2}$ and $\mathrm{Zn}^{+2}$ were increased to $5 \mathrm{mM}$. It is then possible that the initial concentration of $\mathrm{Zn}^{+2}$ in the residues evaluated in this work might be higher than the limit inhibitory concentration and that the addition of zinc reduced laccase activity. Although the inhibitory limit concentration was not determined in this work, the initial concentration of $\mathrm{Zn}^{+2}$ was higher in Rosa than in Chrysanthemum (Table 1). The previous explains why the reduction in laccase activity is higher in the former residue with the same final $\mathrm{Zn}^{+2}$ concentration in the enzymatic reaction. 
Evaluation of the solid fraction obtained from the degradation process of Chrysanthemum and Rosa residues

The adsorption percentages for exoglucanase and $\mathrm{MnP}$ depend largely on the type of waste. In general, more enzymes were adsorbed on Rosa than on Chrysanthemum residues (Table 5); other researchers observed similar behavior. For example, Valášková \& Baldrian (2006) reported the presence of laccase, MnP, exoglucanase, and $\beta$-glucosidase in the solid fraction of a liquid culture of $P$. ostreatus in a synthetic medium; the percentages of adsorption of these enzymes were $38.8 \%, 5.4 \%, 87 \%$ and $65 \%$, respectively. As in this study, the percentage of adsorption of exoglucanase was the highest. This behavior can be explained by the irreversible adsorption of cellulases by the residue, specifically by cellulose, and the addition of surfactants is recommended. Surfactants change the surface tension between the liquid and solid phases and minimize the binding of cellulases to cellulose (Sun \& Cheng 2002).

\section{Conclusion}

In this study, ligninases and cellulases were produced from Chrysanthemum and Rosa residues using P. ostreautus in a submerged culture. Under the conditions evaluated here, the best substrate was the Chrysanthemum residue; the obtained extract had higher enzymatic activity than extracts from the Rosa residue. The highest enzymatic activities for both residues were obtained for laccase and $\beta$-glucosidase and the lowest for endoglucanase. The activity of $\beta$-glucosidase was higher without the presence of inductors, whereas laccase activity was enhanced by the presence of inductors.

\section{Acknowledgements}

The authors acknowledge the financial support from Pontificia Universidad Javeriana and the División de Investigación de la Sede Bogotá (DIB) at Universidad Nacional de Colombia. We also thank Cultivos del Norte for providing the Chrysanthemum and Rosa residues.

\section{Conflict of interest}

Potential conflict of interest none reported.

\section{References}

Asocolflores (2010) Global Reporting Initiative (GRI). www.asocolflores.org. Retrieved January 2014.

Asocolflores, Ministerio de Medio Ambiente y Sociedad de Agricultores de Colombia. (2002). Guía ambiental para la floricultura. www.minambiente.gov.co/documentos/ floricultor.pdf. Retrieved august 2011

ASTM Standard (2008) ASTM D5373-08 . American Standard Test Methods for Instrumental Determination of Carbon, Hydrogen, and Nitrogen in Laboratory Samples of Coal. ASTM International, West Conshohocken. www.astm.org

ASTM standard (2011a) ASTM D4691-11. Standard practice for measuring elements in water by flame atomic absorption spectrophotometry. ASTM International, West Conshobocken. www.astm.org

ASTM Standard (2011b) ASTM D1971-11. Standard practices for digestion of water samples for determination of metals by flame atomic absorption, graphite furnace atomic absorption, plasma emission spectroscopy, or plasma mass spectrometry. ASTM International, West Conshohocken. www.astm.org

Baldrian P, Valášková V (2008) Degradation of cellulose by basidiomycetous fungi. FEMS Microbiology Reviens 32:501-521 doi: 10.1111/j.1574-6976.2008.00106.x

Baldrian P, Vendula V, Merhautová, Gabriel J (2005) Degradation of lignocellulose by Pleurotus ostreatus in the presence of copper, manganese, lead and zinc. Research in Microbiology 156:670-676 doi: 10.1016/j. resmic.2005.03.007

Bettin F, Osorio da Rosa L, Montanari Q et al. (2011) Growth kinetics, production, and characterization of extracellular laccases from Pleurotus sajor-caju PS-2001. Process Biochemistry 46:758-764 doi: 10.1016/j. procbio.2010.12.002

Bhat MK (2000) Cellulases and related enzymes in biotechnology. Biotechnology Advances 18:355-383.

Bourbonnais R, Paice G, Freiermuth B, Bodie E, Borneman $S$ (1997) Reactivities of various mediators and laccases with kraft pulp and lignin model compounds. Applied and Environmental Microbiology 63:4627-4632.

Collins PK, Field J, Dobson A (1996) Oxidation of anthracene and benzo pyrene by laccases from Trametes versicolor. Applied and Environmental Microbiology 62:45634567.

Dekker RFH, Barbosa AM (2001) The effects of aeration and veratryl alcohol on the production of two laccases by the ascomycete Botryosphaeria sp. Ensyme and Microbial Technology 28:81-88. 
Elisashvili V, Penninckx M, Kachlishvili E, Asatiani M, Kvesitadze G. (2006) Use of Pleurotus dryinus for lignocellulolytic enzymes production in submerged fermentation of mandarin peels and tree leaves. 38:9981004 doi: 10.1016/j.enzmictec.2005.08.033

Galhaup CC, Haltrich DD (2001) Enhanced formation of laccase activity by the white-rot fungus Trametes pubescens in the presence of copper. Applied Microbiology and Biotechnology 56:225-32 doi: 10.1007/s002530100636

Ghose T, K (1987) Measurement of cellulase activities. Pure and Applied Chemistry 59:257-268.

Giardina P, Palmieri G, Fontanella B, Rivieccio V, Sannia G (2000) Manganese Peroxidase Isoenzymes Produced by Pleurotus ostreatus Grown on Wood Sawdust. Archives of Biochemistry and Biophysics 376:171-179 doi: 10.1006/ abbi.1999.1691

Huang R, Su R, Qi W, He Z (2011) Bioconversion of Lignocellulose into Bioethanol: Process Intensification and Mechanism Research. Bioenergy Research 4:225-245 doi: 10.1007/s12155-011-9125-7

Isikhuemhen OS, Mikiashvilli NA (2009) Lignocellulolytic enzyme activity, substrate utilization, and mushroom yield by Pleurotus ostreatus cultivated on substrate containing anaerobic digester solids. Journal of Industrial Microbiology \& Biotechnology 36:1353-62 doi: 10.1007/ s10295-009-0620-1

Kumar R, Singh S, Singh OV (2008) Bioconversion of lignocellulosic biomass: biochemical and molecular perspectives. Journal of Industrial Microbiology \& Biotechnology 35:377-91 doi: 10.1007/s10295-008-0327-8

Lin Y, Chen G, Ling M, Liang Z (2010) A method of purification, identification and characterization of $\beta$-glucosidase from Trichoderma koningii AS3.2774. Journal of Microbiological Methods 83:74-81 doi: 10.1016/j. mimet.2010.07.019

Lu X, Ding S (2010) Effect of $\mathrm{Cu}^{2+}, \mathrm{Mn}^{2+}$ and aromatic compounds on the production of laccase isoforms by Coprinus comatus. Mycoscience 51:68-74 doi: 10.1007/ s10267-009-0002-6

Lundell TK, Mäkelä MR, Hildén K (2010) Lignin-modifying enzymes in filamentous basidiomycetes: ecological, functional and phylogenetic review. Journal of Basic Microbiology 50:5-20 doi: 10.1002/jobm.200900338

Malherbe S, Cloete T (2002) Lignocellulose biodegradation: Fundamentals and applications. Reviews in Environmental Science and Biotechnology 105-114

Membrillo I, Sánchez C, Meneses M, Favela E, Loera O (2008) Effect of substrate particle size and additional nitrogen source on production of lignocellulolytic enzymes by Pleurotus ostreatus strains. Bioresource Technology 99:7842-7847 doi: 10.1016/j.biortech.2008.01.083
Murugesan K, Kim Y-M, Jeon J-R, Chang Y-S (2009) Effect of metal ions on reactive dye decolorization by laccase from Ganoderma lucidum. Journal of Hazardous Materials 168:523-529 doi: 10.1016/j.jhazmat.2009.02.075

Palmieri GG, P; Bianco, C; Fontanella, B. (2000) Copper induction of laccase isoenzymes in the ligninolytic fungus Pleurotus ostreatus. Applied and Environmental Microbiology 66:920-924 doi: 10.1128/AEM.66.3.920-924.2000

Quevedo-Hidalgo B, Narváez-Rincón P, Pedroza-Rodríguez A, Velásquez-Lozano M (2012) Degradation of Chrysanthemum (Dendranthema grandiflora) wastes by Pleurotus ostreatus for the production of reducing sugars. Biotechnology and Bioprocess Engineering 17:1103-1112 doi: $10.1007 /$ s12257-012-0227-7

Santoyo F, González AE, Terrón MC, Ramírez L, Pisabarro AG (2008) Quantitative linkage mapping of lignindegrading enzymatic activities in Pleurotus ostreatus. Ensyme and Microbial Technology 43:137-143 doi: 10.1016/j. enzmictec.2007.11.007

Somogy N (1952) Notes on sugar determination. The Journal of Biological Chemistry 195:19-23.

Stajić M, Persky L, Friesem D, et al. (2006) Effect of different carbon and nitrogen sources on laccase and peroxidases production by selected Pleurotus species. Ensyme and Microbial Technology 38:65-73 doi: 10.1016/j. enzmictec.2005.03.026

Sun Y, Cheng J (2002) Hydrolysis of lignocellulosic materials for ethanol production: a review. Bioresource Technology $83: 1-11$

Thakur S, Shrivastava B, Ingale S, Kuhad R, Gupte A (2013) Degradation and selective ligninolysis of wheat straw and banana stem for an efficient bioethanol production using fungal and chemical pretreatment. 3 Biotech 3:365-372 doi: $10.1007 /$ s13205-012-0102-4

Tinoco, Pickard, Vázquez D (2001) Kinetic differences of purified laccases from six Pleurotus ostreatus strains. Letters in Applied Microbiology 32:331-335

Tinoco R, Acevedo A, Galindo E, Serrano-Carreño L (2011) Increasing Pleurotus ostreatus laccase production by culture medium optimization and copper/lignin synergistic induction. Journal of Industrial Microbiology \& Biotechnology 38:531-40 doi: 10.1007/s10295-010-0797-3

Valášková V, Baldrian P (2006) Estimation of bound and free fractions of lignocellulose-degrading enzymes of wood-rotting fungi Pleurotus ostreatus, Trametes versicolor and Piptoporus betulinus. Research in Microbiology 157:119-124 doi: 10.1016/j.resmic.2005.06.004

Van Soest PJ, Robertson JB, Lewis BA (1991) Methods for dietary fiber, neutral detergent fiber, and nonstarch polysaccharides in relation to animal nutrition. 
Symposium: Carbohydrate Methodology, Metabolism, and Nutritional Implications in Dairy Cattle. Journal of Dairy Science 74:3583-3597
Větrovský T, Baldrian P, Gabriel J (2013) Extracellular enzymes of the white-rot fungus Fomes fomentarius and purification of 1,4-[beta]-glucosidase. Applied Biochemistry and Biotechnology 169:100-9 doi: 10.1007/ s12010-012-9952-9
Producción de enzimas lignocelulolíticas a partir de residuos de floricultura empleando Pleurotus ostreatus

Resumen. En Colombia la floricultura es un sector agroindustrial importante, con impactos positivos en el empleo y la balanza comercial. Sin embargo, tiene impacto negativo en el medio ambiente porque genera alto volumen de residuos. Estos residuos, ricos en lignina, hemicelulosa y celulosa, podrían ser una materia prima de bajo costo para la producción de enzimas. En este trabajo se estudió en la producción de enzimas lignocelulíticas por la degradación con Pleurotus ostreatus de residuos de Chrysanthemum y Rosa, usando como inductores sulfato de manganeso y de cobre. A partir de ambos residuos se obtuvieron lacasa, manganeso peroxidasa, endoglucanasa, exoglucanasa y $\beta$-glucosidasa. Los inductores favorecieron todas las actividades enzimáticas, excepto para $\beta$-glucosidasa. Las enzimas que tuvieron mayores actividades fueron lacasa (4,693.4 U/L y 2,640 U/L a partir del residuo de Chrysanthemum y Rosa, respectivamente) y $\beta$-glucosidasa $(9,513$ U/L y 6,811.9 U/L). La enzima que tuvo menor actividad fue endoglucanasa (11.5 U/L y $15.4 \mathrm{U} / \mathrm{L})$. Bajo las condiciones evaluadas, el mejor residuo para producción de enzimas fue Chrysanthemum, porque los extractos tuvieron mayor actividad enzimática que los producidos a partir de Rosa.

Palabras clave: residuos de floricultura; Chrysanthemum; Rosa; enzimas lignocelulolíticas; Pleurotus ostreatus
Produçáo de enzimas lignoceluliticas a partir de resíduos de floricultura utilizando Pleurotus ostreatus

Resumo. Na Colômbia, a floricultura é um importante setor da indústria agrícola, com impactos positivos sobre o sector laboral na balança comercial. Além disto, tem impacto negativo sobre o meio ambiente, pois gera grandes volumes de resíduos. Estes resíduos, com altos conteúdos em lignina, hemicelulose e celulose, podem ser uma matéria-prima de baixo custo para a produção de enzimas. Neste trabalho foi estudada a produção da enzimas lignoceluliticas pela degradação com Pleurotus ostreatus de resíduos de Chrysanthemum e Rosa, utilizando como indutores sulfatos de cobre e manganês. A partir destes resíduos foram obtidos lacase, manganês peroxidase, endoglucanase, exoglucanase e $\beta$-glicosidase. $\mathrm{O}$ uso de indutores favoreceu as atividades enzimáticas, exceto $\beta$-glicosidase. As enzimas que apresentaram atividades mais elevadas foram lacase $(4,693.4 \mathrm{U} / \mathrm{L}$ e 2,640 U/L a partir do Chrysanthemum e Rosa, respetivamente) e $\beta$-glicosidase (9,513 U/Le 6,81.9 U/L). A enzima que apresentou menor atividade foi a endoglucanase (11.5 U/L e 15.4 U/L). Nas condições testadas, o melhor resíduo para a produção da enzima foi Chrysanthemum, porque os extratos tinham uma atividade enzimática mais elevada que aqueles produzidos a partir de Rosa.

Palavras-chave: resíduos de floricultura; Chrysanthemum; Rosa; enzimas lignoceluliticas; Pleurotus ostreatus 